\title{
СТРУКТУРНО-ДИНАМІЧНА МОДЕЛЬ РОЗВИТКУ ЕМОЦЙНОГО ІНТЕЛЕКТУ В ЮНАЦЬКОМУ ВІЦІ
}

\author{
Лаас М. В., аспірантка кафедри сочіальної та практичної психології \\ Житомирський державний університет імені Івана Франка, м. Житомир, Україна
} ORCID ID: https://orcid.org/0000-0002-8473-4188

DOI: https://doi.org/10.31435/rsglobal_conf/25122020/7312

\begin{abstract}
The article is devoted to the development of a structural-dynamic model of the development of intrapersonal and interpersonal emotional intelligence in adolescence, in relation to the selected components of emotional intelligence and empathy.

Through the analysis of the concept of emotional intelligence and its structural components, factors, selected the structural components of intrapersonal and interpersonal emotional intelligence, determined by empathy: conative component (self-control over one's own emotions, emotional lability, stress-resistance; maintaining relationships, control over the emotions of others); motivational component (self-motivation, how to support and evoke positive emotions that motivate activity; the need for affiliation and cooperation, the need to control the emotions of others, social responsibility); cognitive component (self-knowledge, understanding of own emotions, their use in mental activity, self-understanding; understanding of emotions of others); emotional component (emotionality, expression and identification of own emotions, positivity, perception of emotions of others).
\end{abstract}

Keywords: emotional intelligence, intrapersonal emotional intelligence, interpersonal emotional intelligence, empathy, forms of empathy, components of emotional intelligence, empathy.

Вступ. Сучасне суспільство постійно зазнає змін, що призводять до актуалізації досліджень емоційного інтелекту, адже він допомагає досягти успіху, утримувати соціальні зв'язки та розвивати їх, вчитися розуміти себе, власні емоції та інших. На розвиток емоційного інтелекту впливають внутрішні чинники, як саморегуляція, емпатія, мотивація, рефлексія та інші. Зокрема, особливу увагу приділяють емпатії, як чиннику розвитку емоційного інтелекту та як психологічному процесу, що дозволяє одній людині зрозуміти переживання іншого та трансформувати їх у власні. Вона $€$ засобом соціалізації й адаптації людини до навколишнього середовища.

Емоційний інтелект досліджувався українськими (С. Дерев’янко [6], Е. Носенко [9]) та зарубіжними вченими (Г. Гарднер [3], Д. Гоулман [5]). Вивчався взаємозв'язок емоційного інтелекту з соціальною та комунікативною компетентністю (Р. Бар-Он [2]), самоактуалізацією особистості (І. Андреєва [1]).

Г. Гарднер висунув думку про множинність форм прояву інтелекту. До них належать такі: вербальний, просторовий, кінестетичний, логіко-математичний, музичний). Він вважав, що внутрішньоособистісний інтелект є ключем до самопізнання, а міжособистісний інтелект це здатність розуміти інших людей. Недостатнім $\epsilon$ вивчення структурних елементів емоційного інтелекту у юнацькому віці, детермінованих емпатійністю.

Мета статті. Розробити структурно-динамічну модель розвитку емоційного інтелекту у юнацькому віці, детерміновану емпатійністю.

Результати. Емоційний інтелект розглядається як здатність людини тлумачити власні емоції і емоції оточуючих 3 тим, щоб використовувати отриману інформацію для реалізації власних цілей $[4$, с. 51].

Д. Гоулман виділяє п'ять складових емоційного інтелекту: знання власних емоцій, ïx самоусвідомлення, управління емоціями, самомотивація, емпатія, підтримання взаємостосунків. Такий чинник розвитку емоційного інтелекту як емпатія $\epsilon$ чи не одним 3 головних у розвитку емоційного інтелекту. Журавльова Л. П. вважає, що емпатія - особлива форма психічного відображення суб'єктом (емпатуючим) об'єктивної реальності, що опосередкована внутрішнім світом суб'єкта (емпата). Суть емпатії полягає у відображенні суб'єктом емпатії переживань емпата i трансформації цих пережив, у власні. [8, с.154]. Також існують форми прояву емпатії: антиемпатія, індиферентність, співпереживання, співчуття, внутрішнє сприяння, реальне сприяння не на шкоду собі та реальне сприяння на шкоду собі або ж альтруїстична емпатія. На думку Сопикова А. П. існує три види емпатії: емоційна, пізнавальна, поведінкова [10]. 
Представник особистісного підходу Г. Гарднер визначив поняття «емоційний інтелект» y двох формах: міжособистісний і внутрішньоособистісний [4]. Під міжособистісним емоційним інтелектом розглядається здатність людини розуміти інших, усвідомлювати мотиви їхньої поведінки та ставлення до роботи, обирати шляхи ефективної співпраці з оточуючими. Під внутрішньоособистісним емоційним інтелектом - властивість людини, спрямовану на себе, здатність формувати точну, адекватну модель власного «Я» та використовувати іiі для ефективної життєдіяльності.

Спираючись на такий поділ емоційного інтелекту, його структуру та використовуючи зв'язок з емпатійністю, виокремлено компонети розвитку емоційного інтелекту у юнацькому віці. Емпатійність у кожному з представлених компонентів забезпечується механізмами, які пов'язані між собою (Рис. 1).

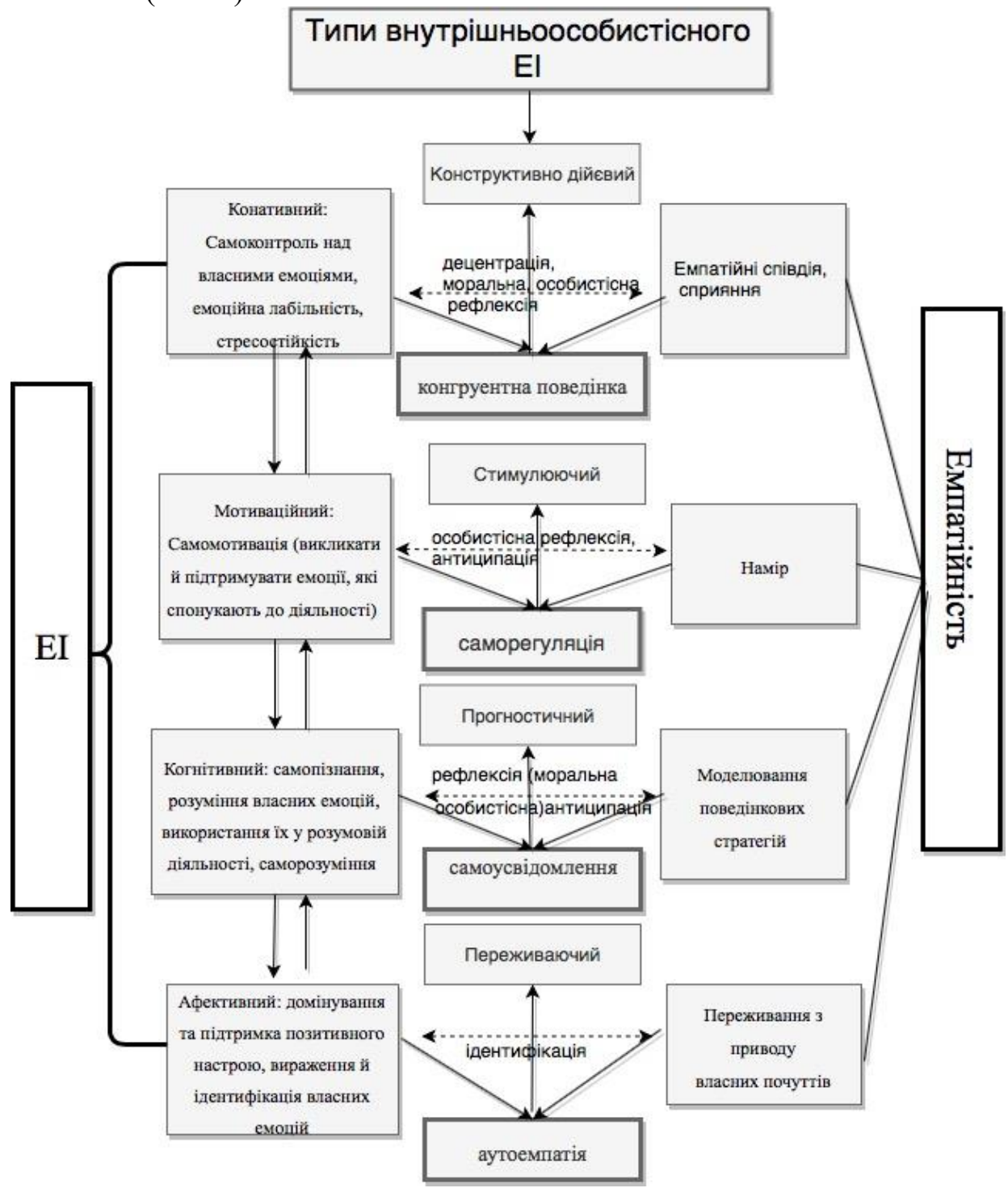

Рис. 1 Структурні компоненти внутрішньособистісного емоційного інтелекту

У внутрішньоособистісному емоційному інтелекті виділено афективний, когнітивний, мотиваційний, конативний компоненти.

Базовими характеристиками афективного компоненту $\epsilon$ домінування позитивного настрою, вираження, ідентифікація емоцій, переживання з приводу власних почуттів. В основі функціонування афективного компоненту лежить механізм ідентифікації, який зумовлює реалізацію переживаючого типу внутрішньоособистісного емоційного інтелекту. Особистість виражає власні емоції, переживає, проявляє експресивність, зосереджена лише на собі. Переживання емоцій проявляється в зовнішніх виявах: міміці, жестах, рухах, серцебитті та інші. Вираження різних емоції призводять до підвищення або зниження життєдіяльності, появи 
потреб, до змін у процесах, що відбуваються в організмі. Позитивні емоції сприяють активній життєвій позиції, успіху, негативні ж можуть як допомогти досягти успіху, через вольовий компонент, мотивацію досягнення успіху, так і заважати досягненню цілей через страх невдачі, неприйняття. Люди самовизначають себе через свої емоції.

Складовими когнітивного компоненту є самопізнання, розуміння власних емоцій та використання їх у розумовій діяльності, саморозуміння в поєднанні з моделюванням поведінкових стратегій. В основі функціонування цього компоненту лежать механізми: особистісна рефлексія, антиципація. Вони допомагають самоусвідомити, проаналізувати особистісні якості, інтереси 3 етичними та моральними нормами, пізнати себе та свої емоції, передбачити як вдало застосовувати їх. Вони зумовлюють прогностичний тип емоційного інтелекту, який не оснований на діях, а лише продумує їх хід для конструктивного вирішення питань. Такий тип допомагає адекватно оцінити себе, свої справжні потреби, бажання. Розуміння власних емоцій починається зі здатності розпізнати, розуміти причини виникнення і наслідки, до яких вони призведуть. Прогностичний інтелект забезпечує створення системи ментальних моделей світу через когнітивні складові, адаптуючи цю модель до власних бажань і визначаючи себе в ній.

Характеристиками мотиваційного компоненту є самомотивація, яка основана на тому, щоб викликати та підтримувати позитивні емоції, що спонукають до діяльності в поєднанні з наміром. В основі функціонування цього компоненту лежать механізми: особистісна рефлексія та антиципація, що зумовлюють стимулюючий тип емоційного інтелекту. Людина завдяки мотивації спонукає себе відчувати потрібні емоції, завдяки яким виникає намір до дії. 3 самомотивацією пов'язані самоорганізація, самостимулювання, самопідштовхування себе до цілі. Рушійною силою самомотивації є актуальні для особистості цілі, їх значущість, потреба їх досягати.

Базовими складовими конативного компоненту є самоконтроль над власними емоціями, емоційна лабільність, стресостійкість в поєднанні з емпатійною співдією та сприянням. В основі функціонування цього компоненту лежать механізми: децентрація, особистісна та моральна рефлексія, що зумовлюють конструктивно-дієвий тип емоційного інтелекту. Завдяки їм особа вміє контролювати свої емоції, адаптуватися до певних умов та стійко реагувати в різних ситуаціях, виробити на цій основі конструктивну поведінку. Показником розумного управління емоціями $є$ емоційна врівноваженість, яка не може бути досягнута тільки шляхом ситуативного контролю та переживаннями, де людина переходить до керування ситуацією, в якій виникають і проявляються емоції. Здібність керувати власними емоціями дозволяє розвивати ініціативність та вміння працювати в стресогенних умовах.

Отже, у внутрішньоособистісному емоційному інтелекті виділи типи, детерміновані емпатійністю: переживаючий, прогностичний, стимулюючий та конструктивно-дієвий, які взаємодіють між собою.

У розвитку міжособистісного емоційного інтелекту (Рис.2) базовими характеристиками афективного компоненту є сприйняття емоцій інших та їх ідентифікація, переживаннями з приводу почуттів Іншого. В основі функціонування афективного компоненту лежить механізм ідентифікації та емоційне зараження, які зумовлюють реалізацію співпереживаючого типу емоційного інтелекту. Особистість ідентифікує свої емоції 3 емоціями іншого, розуміє їх через усвідомлене чи неусвідомлене ототожнення з власними, емоційно заражається від інших. Проявляється чуйність до іншого. При такій взаємодії інтереси людини стають дещо вагомішими за власні. Людина здатна емоційно реагувати на переживання інших людей, проникати в їхній внутрішній світ, розуміти їхні переживання, думки, почуття, переживати ті самі емоції, що й інша людина, через ототожнювання 3 нею. Це допомагає відчути підтримку, розуміння й будувати відносини х іншими.

Складовими когнітивного компоненту $€$ розуміння й аналіз емоцій інших та моделюванням поведінкових стратегій. В основі функціонування цього компоненту лежать механізми: рефлексія (соціальна, моральна), антиципація. Вони допомагають проаналізувати особистісні риси іншої людини, інтереси з етичними та моральними нормами, пізнати емоції іншої людини та на основі цього скласти узагальнений образ людини: який іiі настрій, що вона відчуває. Це допоможе вірно змоделювати поведінку у взаємодії з іншим. Вони зумовлюють аналізуючий тип емоційного інтелекту, який не оснований на діях, а лише заздалегідь визначає ïх хід для конструктивного вирішення питань. Прояв емоцій може як активувати когнітивний процеси і впливати на них, так і навпаки, процеси активувати прояв певних емоцій. Розуміння емоцій інших сприяє розвитку вміння впливати на людей та надихати їх на певні дії. 
Характеристиками мотиваційного компоненту $є$ потреба в афіліації та співпраці, потреба у контролі емоцій інших, соціальна відповідальність. В основі функціонування цього компоненту лежать механізми: соціальна та особистісна рефлексія, антиципація, що зумовлюють афіліаційний тип емоційного інтелекту.

Людина потребує спілкування з іншими, взаємодії, приналежності до соціуму, що призводить до виникнення наміру взаємодії з іншими. Потреба у спілкуванні та приналежності до соціуму допомагає встановлювати з іншими довірливі, позитивні відносини. Зовнішньо це може проявлятися в дружелюбному виразі обличчя, збільшенні тривалості контакту очей, повторі жестів співрозмовника. Особистість прихильна до інших, товариська, легко співпрацює 3 іншими людьми, постійно знаходитись поруч 3 ними. В результаті задоволення мотиву афіліації між людьми створюються довірливі, щирі стосунки, засновані на симпатіях та взаємодопомозі. Особистості з розвиненим мотивом афіліації виявляють велику активність i ініціативу в спілкуванні з оточуючими [7].

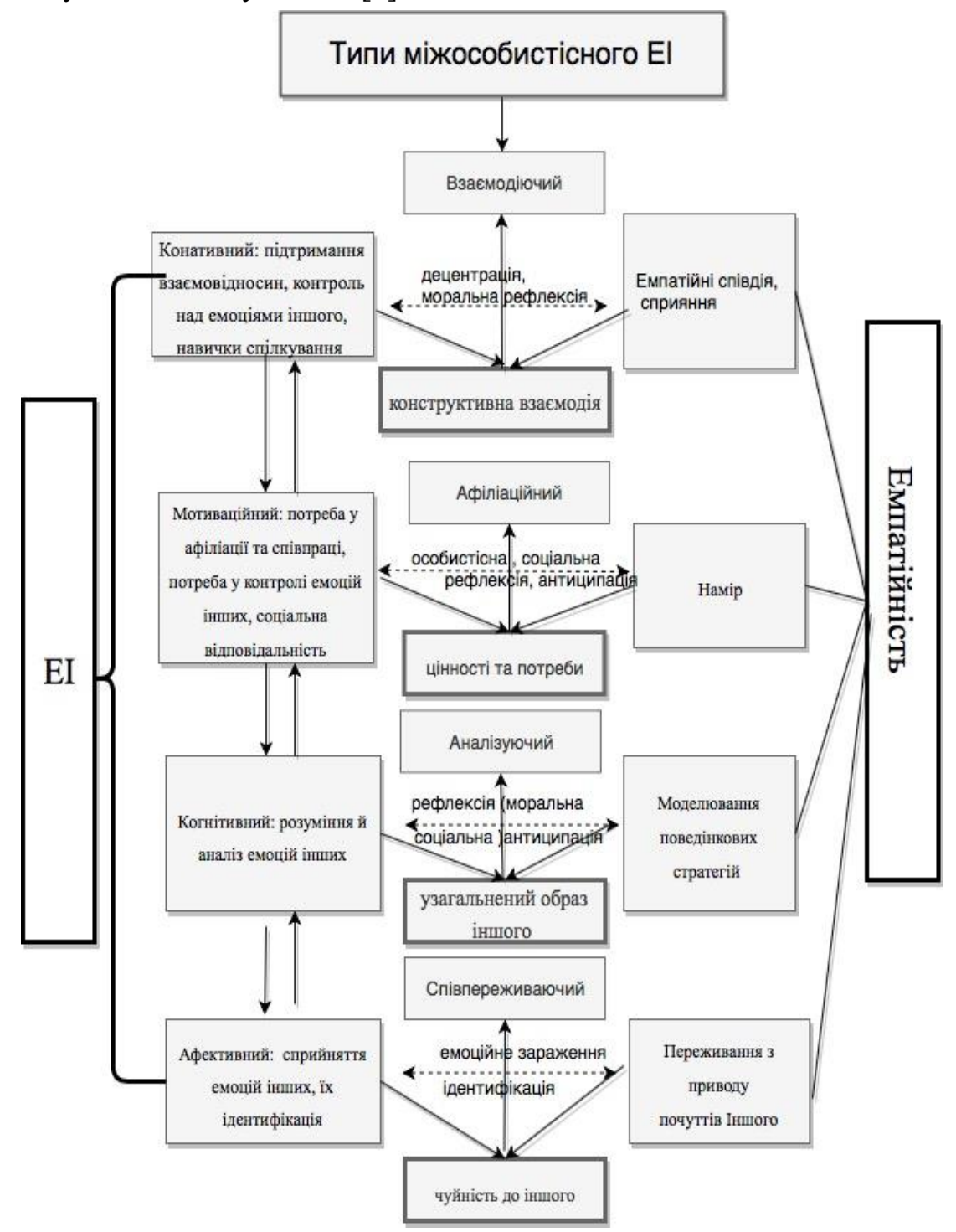

Рис. 2 Структурні компоненти міжособистісного емоційного інтелекту

Базовими складовими конативного компоненту $є$ підтримання взаємовідносин, контроль над емоціями іншого, навички спілкування в поєднанні з емпатійною співдією та сприяння. В основі функціонування цього компоненту лежать механізми: децентрація та моральна рефлексія, що зумовлюють взаємодіючий тип емоційного інтелекту. Завдяки їм особа легко встановлює та підтримує контакти 3 іншими, активно взаємодіє 3 іншими, завдяки навичкам спілкування, контролює емоції інших. Децентрація та моральна рефлексія допомагають проявляти конструктивну поведінку у взаємодії з оточуючими. 
Спілкування сприяє прояву раніше засвоєних емоційних знань людини. Емоції $є$ важливою складовою спілкування, при цьому вони можуть мати як деструктивний, так i конструктивний характер. Деструктивне спілкування охоплює дії, що тією чи іншою мірою перешкоджають спільній діяльності, створюючи перепони на шляху до порозуміння (конкуренція, конфлікт). Неконструктивне управління емоціями проявляється у трьох формах вираження: придушенні, маскуванні, симуляції непережитої емоції, що призводить до порушення емоційного здоров'я.

Афективний, когнітивний, мотиваційний та конативний компоненти емоційного інтелекту взаємодіють між собою так і між його типами.

Отже, у міжособистісному емоційному інтелекті виділи типи, детерміновані емпатійністю: співпереживаючий, аналізуючий, афіліаційний та взаємодіючий.

Висновки. Отже емоційний інтелект - це система емоційних, когнітивних, комунікативних та регуляційних здібностей особистості, яка допомагає людині будувати кар'єру, утримувати та розвивати соціальні зв'язки, створювати сім'ї та зберігати їх. Він $є$ невід'ємною складовою життя, завдяки якій досягається успіх, розуміння себе, власних емоції та інших.

Через аналіз поняття емоційного інтелекту та його структурних компонентів, чинників, виділено структурні складові внутнішньоособистісного та міжособистісного емоційного інтелекту, детерміноватих емпатійністю: конативний компонент (самоконтроль над власними емоціями, емоційна лабільність, стресостійкість; підтримання взаємовідносин, контроль над емоціями інших); мотиваційний компонент (самомотивація, як підтримувати і викликати позитивні емоції, які спонукають до діяльності; потреба у афіліації та співпраці, потреба у контролі емоцій інших, соціальна відповідальність); когнітивний компонент (самопізнання, розуміння власних емоцій, використання їх у розумовій діяльності, саморозуміння; розуміння емоцій інших); емоційний компонент (емоційність, вираженість та ідентифікація власних емоцій, позитивність, сприйняття емоцій інших).

\section{REFERENCES}

1. Andreeva I. N. (2004) Ponyatie i struktura emotsional'nogo intellekta [The concept and structure of emotional intelligence]. Sotsial'no-psikhologicheskie problemy mental'nosti: 6-ya mezhdunar. nauch.-prakt. konf. (Smolensk, 2004.) Smolensk: SGPU, pp. 22.

2. Bar-On R. The Bar-On model of emotional-social intelligence (ESI) / Reuven Dar-On. Psicothema. 2006, vol.18, pp.13-25.

3. Gardner H. Multiple intelligences. N.Y., 1993, pp. 352.

4. Gardner Govard. (2007) Struktura razuma: teoriya mnozhestvennogo intellekta [The structure of mind: theory of multiple intelligences]. OOO «I. D. Vil'yams», pp. 281.

5. Goulman D. (2009) Emotsional'nyy intellect [Emotional intelligence]. M.: ACT M., pp. 478

6. Derev'janko S. P. (2008) Aktualizacija emocijnogho intelektu v emocioghennykh umovakh [Actualization of emotional intelligence in emotional conditions]. Socialjna psykhologhija. no.1, pp. 96-104.

7. Emishjanc O.B. (2011) Procesualjni aspekty funkcionuvannja osobystosti. [Procedural aspects of personality functioning] Aktualjni problemy sociologhiji, psykhologhiji, pedaghoghiky. vol. 13, pp.137-142.

8. Zhuravljova L.P. (2007) Psykhologhija empatiji [Psychology of empathy]: monoghrafija. Zhytomyr: Vydvo $\mathrm{ZhDU}$ im. I.Franka, pp. 328.

9. Nosenko E. L. (2003) Emocijnyj intelekt: konceptualyizacija fenomenu, osnovni funkcii [Emotional intelligence: conceptualization of the phenomenon, basic functions]: monoghrafija. K.: Vyshha shkola, pp. 126.

10. Sopikov A.P. (1977) Mekhanizm empatiji [The mechanism of empathy] Pytannja psykhologhiji piznannja ljudjmy odyn odnogho i samopiznannja. Krasnodar, pp. 86-89. 